Vol. 5. No. 1 Tahun 2016

\title{
Penerapan Model Pembelajaran Kooperatife STAD Untuk Meningkatkan Hasil Belajar Siswa Mata Pelajaran IPA
}

\author{
Armiyati \\ Program Studi Teknologi Pendidikan Pascasarjana UIKA Bogor \\ Jl. KH. Sholeh Iskandar Km. 2 Kd. Badak, Bogor \\ (jurnal@ppsuika.ac.id)
}

\begin{abstract}
Abstrak: Penelitian ini merupakan penelitian tindakan kelas (PTK). Dilaksanakan secara kolaboratif antara penulis, observer, dan subjek yang diteliti. Tujuan utama dalam penelitian ini adalah untuk meningkatkan hasil belajar mata pelajaran ipa pada siswa kelas VI melalui penerapan model pembelajaran Student Teams Achievement Divisions (STAD). Subjek penelitian adalah siswa-siswi kelas VI di Sekolah Dasar Negeri Balandongan yang terdiri dari 17 siswa laki-laki dan 13 siswa perempuan. Pelaksanaan penelitian dilaksanakan pada semester ganjil tahun 2015/2016. Hasil penelitian menunjukan bahwa nilai hasil belajar pada tes awal sebesar 29,17\%, siklus I pertemuan 1 nilai sebesar 37,50\%, dan siklus I pertemuan 2 nilai sebesar 62,50 \%, sedangkan siklus II memperoleh nilai $83,3 \%$, peningkatan hasil belajar dari siklus I dan siklus II sebesar $46 \%$. Hasil belajar siswa memperoleh nilai rata-rata pada tes awal sebesar 50 kategori "C" kualifikasi "Cukup Berkualitas", siklus I pertemuan 1 memperoleh nilai rata-rata sebesar 60,80 kategori "B" kualifikasi "Berkualitas", siklus 1 pertemuan 2 memperoleh nilai 68,30 katagori "B" kualifikasi "Berkualitas", sedangkan siklus II memperoleh nilai rata-rata 73,00 kategori "B" kualifikasi " Berkualitas", peningkatan hasil belajar dari siklus I dan siklus II sebesar 11,70. Penelitian ini berkesimpulan bahwa penerapan Model Pembelajan Student Teams Achievement Divisions (STAD). dapat meningkatkan hasil belajar mata pelajaran IPA pada siswa kelas VI di Sekolah Dasar Negeri Balandongan Kecamatan Caringin Kabupaten Bogor. Selain itu, model pembelajaran ini juga dapat meningkatkan kerjasama, ketelitian, dan disiplin siswa dalam pembelajaran IPA.
\end{abstract}

Kata Kunci : Hasil Belajar, STAD, IPA.

Abstract: This research is a Classroom Action Research (CAR). Commissioned jointly between writer, observer, and the subject under study. The main objective of this research is to improve the learning outcomes of the subjects of Social Studies at the VI grade students through the implementation of cooperative learning model Student Teams Achievement Divisions(STAD). Subjects were students in an elementary school classroom VI Balandongan Elementary School which consists of 17 male students and 14 female students. Implementation of the research carried out in odd semester 2015/2016 The results showed that the learning outcomes at the beginning of the test obtained at 29,17\%, the first cycle to obtain a value of $37,50 \%$, while the second cycle gain value of $83,3 \%$, improvement of learning outcomes from the first cycle and seconpd cycle of $46 \%$. Learning outcomes scored an average of 50 category " $C$ " qualification "Good", at the beginning of the test cycle, I scored an average of 68,30 category " $B$ " qualification "Good", while the second cycle to obtain the average value of 73 category "B" qualification "Good", improving the learning outcomes of the first 
cycle and second cycle of 11,72. This study concluded that the implementation of Cooperative Learning Model Student Teams Achievement Divisions(STAD) can improve learning outcomes subjects of Math at the VI grade students in Balandongan Elementary School District Caringin, Bogor Regency. In addition, the learning model can also improve cooperation and participation of students in learning Natural Science.

Keyword : Learning Outcomes, STAD,Natural Science.

\section{PENDAHULUAN}

Pembelajaran IPA diperlukan pembelajaran yang aktif, inovatif dan menyenangkan, pembelajaran yang tidak membuat bosan kepada siswa, menggunakan model pembelajaran yang menyenangkan, dan media yang menarik. Sehingga nilai matematika dapat ditingkatkan menjadi lebih baik, namun dalam kenyataan di Sekolah Dasar Negeri Balandongan hasil belajar mata pelajaran IPA rendah. Hal ini dimungkinkan oleh faktor-faktor penyebab antara lain 1) Pelajaran Matematika kurang diminati oleh sebagian siswa, 2) peran guru lebih besar sehinggga siswa menjadi tidak aktif, 3) guru tidak menggunakan media pembelajaran yang menarik, 4) guru tidak menerapkan metoda pembelajaran yang bervariasi, 5) guru tidak menerapkan model pembelajaran yang tepat, 6) kemampuan guru dalam memanfaatkan media/alat peraga pada penyampaian materi ternyata masing kurang dan 7) guru dalam menentukan nilai kriteria ketuntasan minimal terlalu tinggi.

Dari masalah-masalah yang dikemukakan di atas, perlu dicari strategi baru dalam pembelajaran yang melibatkan siswa secara aktif. Pembelajaran yang mengutamakan penguasaan kompetensi harus berpusat pada siswa, memberikan pembelajaran, pengalaman belajar yang relevan dan kontekstual dalam kehidupan nyata.

Disinilah guru dituntut untuk merancang kegiatan pembelajaran yang mampu mengembangkan kompetensi, baik dalam ranah kognitif, ranah afektif maupun psikomotorik siswa. Salah satunya model pembelajaran kooperatif STAD, penulis tertarik menerapkan model pembelajaran ini dikarenakan pada saat proses pembelajaran siswa menggunakan model pembelajaran tim siswa kelompok prestasi yang akan membuat siswa menjadi aktif, senang, 
bekerja sama yang dapat memengaruhi hasil belajar siswa menjadi meningkat.

Berdasarkan latar belakang di atas maka rumusan penelitian ini adalah : "Apakah penerapan model pembelajaran kooperatif STAD dapat meningkatkan hasil belajar siswa mata pelajaran IPA pada materi konduktor dan isolator siswa kelas VI SDN Balandongan Kecamatan Caringin Kabupaten Bogor?".

$$
\text { Pada proses pembelajaran }
$$
mengandung dua unsur yang sangat penting yaitu proses dan hasil belajar. Dalam setiap proses pembelajaran guru ingin mendapatkan hasil belajar yang baik, yang berupa hasil belajar yang mencapai nilai maksimal. Dan hasil belajar sendiri merupakan sebuah kalimat yang terdiri dari dua kata yaitu "hasil" dan "belajar" yang memiliki arti sangat yang berbeda.

Menurut Mulyono Abdurahman (2009:38) berpendapat bahwa : Hasil belajar adalah kemampuan yang duperoleh anak setelah melalui kegiatan belajar. Belajar itu sendiri merupakan suatu proses dari seseorang yang berusaha untuk memperoleh suatu bentuk perubahan perilaku yang relative menetap.
Pendapat lain dikemukakan oleh Nana Sujana (Bandung,2009:9) dalam buku penelitian hasol proses belajar mengajar berbendapat bahwa: Hasil belajar adalah kemampuankemampuan yang dimiliki siswa setelah ia menerima pengalaman belajarnya. Jadi hasil belajar akan didapat siswa setelah mengalami proses belajar dalam bentuk kemampuan-kemapuan tertentu.

Banyak faktor-faktor yang mempengaruhi hasil belajar siswa, baik yang berasal dari dalam diri maupun dari luar diri siswa itu sendiri.

H.Aminudin Lubis (2003:103) membagi factor itu menjadi : 1) Faktor Internal (dari dalam individu yang belajar) factor dari dalam diri antara lain seperti : minat belajar, kesehatan, ketenangan jiwa, motivasi, kegairahan diri, cita-cita, kebugaran jasmani, kepekaan alat-lat indra siswa, dan perhatian. 2)Faktor dari luar diri antara lain: keadaan lingkungan belajar, cuaca, letak sekolah, interaksi social, alat-alat belajar yang digunakan guru dalam pengajaran seperti media pendidikan, metodologi menhajar, dan buku-buku yang digunakan.

Secara sederhana kata "kooperatif" berarti mengerjakan 
sesuatu dengan cara bersama-sama dengan saling membantu satu sama lainnya sebagai satu tim. Artzt \& Newman dalam Trianto (2009:58) menyatakan bahwa model pembelajaran kooperatif siswa belajar bersama sebagai suatu tim dalam menyelesaikan tugas-tugas kelompok untuk mencapai tujuan bersama.

Tujuan pokok pembelajaran kooperatif adalah memaksimalkan belajar siswa untuk peningkatan prestasi akademik dan pemahaman baik secara individu maupun secara kelompok, karena siswa belajar dalam suatu tim, maka dengan sendirinya dapat memperbaiki hubungan antara para siswa dari berbagai latar belakang, etnis dan kemampuan, mengembangkan keterampilanketerampilkan proses kelompok dan pemecahan masalah. Manfaat penerapan model pembelajaran kooperatif adalah mengurangi kesenjangan pendidikan khususnya dalam wujud input level individual, disamping itu model pembelajaran kooperatif dapat mengembangkan solidaritas sosial dikalangan siswa diharapkan kelak akan muncul generaso baru yang memiliki pretasi akademik yang cemerlang dan memiliki solidaritas yang kuat.

Model pembelajaran kooperatif Make A Match adalah salah satu model pembelajaran kooperatif yang menggunakan kartu-kartu sebagai media pembelajarannya. Riyanto (2009 :61) dalam melaksanakan tugas sebagai fasilitator, guru harus mempersiapkan terlebih dahulu cara-cara untuk mencapai tujuan pembelajaran. Mencari pasangan (Make A Match) adalah model pembelajaran mencari pasangan, karena dalam model pembelajaran ini siswa diminta untuk mencari pasangan dari temannya sendiri yang mempunyai kesesuaian antara soal dan jawaban yang cocok.

Model pembelajaran kooperatif tipe Mencari Pasangan (Make A Match) memiliki nilai-nilai positif atau kelebihan yaitu: 1) Ada unsur masyarakat belajar (learning community),2) Dapat mengembangkan kemampuan (life skill), 3) Adanya unsure permainan (game).

Kelemahan model pembelajaran kooperatif Make A Match adalah banyak mrnyita waktu guru dalam menyiapkan kartu dan perangkat pendukungnya. Cukup menimbulkan kegaduhan karena tidak jarang siswa 
berteriak, kegirangan ketika kartu jawaban yang diambilnya ternyata cocok dengan soal yang dipegangnya.

Dimasa yang akan datang siswa akan menghadapi tantangan berat karena kehidupan masyarakat global selalu mengalami perubahan setiap saat. Oleh karena itu mata pelajaran Matematika dirancang untuk mengembangkan pengetahuan, pemahaman, dan kemampuan, analisis terhadap kondisi sosial masyarakat dalam memasuki kehidupan bermasyarakat yang dinamis.

Powler (dalam Usman Samatowa, 2006: 2), IPA merupakan ilmu yang berhubungan dengan gejala-gejala alam dan kebendaan yang sistematis yang tersusun secara teratur, berlaku umum yang berupa kumpulan dari hasil observasi dan eksperimen

\section{METODOLOGI}

\section{PENELITIAN}

Penelitian ini bertujuan untuk mengetahui peningkatan hasil belajar siswa dalam pembelajaran Matematika kelas VI, materi Konduktor dan isolator, di SD Negeri Balandongan Kecamatan Caringin, Kabupaten Bogor melalui model pembelajaran STAD antara lain : Pelaksanaan penelitian tindakan kelas ini dilaksanakan di Sekolah Dasar Negeri Balandongan Kabupaten Bogor yang berlokasi di Jl. Mayjen H.R Edi Sukma Kp. Balandongan Ds. Ciherangpondok. Pelaksanaan penelitian dilaksanakan pada tanggal 33, 30, September dan7 Oktober 2015 yang dilakukan pada semester ganjil tahun ajaran 2015/2016. Subjek penelitian adalah siswa-siswi di Sekolah Dasar Negeri Balandongan Kecamatan Caringin Kabupaten Bogor yang berjumlah 31 orang terdiri atas 17 siswa perempuan dan 14 siswa laki-laki.

Teknik pengumpulan data pada penelitian ini melalui observasi,wawancara tes, dan dokumentasi. Instrumen pengumpulan data mengunakan instrumen penilaian pelaksanaan pembelajaran di kelas (penilaian kinerja guru), lembar observasi aktivitas siswa, dan penilaian/tes.

Analisis data yang diterapkan dalam penelitian tindakan kelas adalah statistik deskriptif sederhana, dengan langkah-langkah statistik sebagai berikut: Mentabulasi data hasil observasi dan penilaian (tes), dan 
memperoleh nilai rata-rata (mean) atau dengan rumus:

$$
\mathrm{X}=\frac{\Sigma \mathrm{Xi}}{\mathrm{n}}
$$

atau Rata-rata persentase

$$
\mathrm{X}=\frac{\sum \times \mathrm{i}}{\mathrm{n}} \times 100 \%
$$

Keterangan:

$\mathrm{X}=$ nilai rata-rata atau rata-rata presentase

$X_{i}=$ nilai $x$ ke 1 sampai ke $n$

$\mathrm{n}=$ jumlah siswa

Dengan adanya perbaikan kualitas pembelajaran Matematika di kelas VI SDN Balandongan Kecamatan Caringin Kabupaten Bogor dengan menggunakan model pembelajaran STAD, maka indikator keberhasilan penelitian adalah $80 \%$ dari jumlah 31 siswa mencapai hasil belajar mencapai KKM sebesar 71 .

\section{HASIL DAN PEMBAHASAN}

\subsection{Temuan Penelitian}

Sebelum penelitian ini dilaksanakan, penulis terlebih dahulu melaksanakan pra siklus yaitu dengan memberikan tes awal kepada siswa. Dari hasil tes awal tersebut diperoleh nilai rata-rata sebesar 50,41 .Untuk lebih jelasnya dapat dilihat pada Tabel 1 berikut:
Tabel 1. Persentase Ketuntasan Tes Awal Siswa

\begin{tabular}{|c|c|c|c|}
\hline $\begin{array}{c}\text { No } \\
\cdot\end{array}$ & $\begin{array}{c}\text { Ketuntasa } \\
\mathrm{n}\end{array}$ & $\begin{array}{c}\text { Jumla } \\
\mathrm{h} \\
\text { Siswa }\end{array}$ & $\begin{array}{c}\text { Presentas } \\
\mathrm{e}\end{array}$ \\
\hline 1. & Tuntas & 7 & $22,58 \%$ \\
\hline 2. & $\begin{array}{c}\text { Belum } \\
\text { Tuntas }\end{array}$ & 24 & $77,42 \%$ \\
\hline \multicolumn{2}{|c|}{ Jumlah } & 31 & $100 \%$ \\
\hline
\end{tabular}

Berdasarkan Tabel 1 di atas dapat diketahui, dari 31 siswa terdapat 7 siswa atau 22,58\% yang sudah mencapai ketuntasan belajar, sedangkan siswa yang memperoleh nilai di bawah KKM ada 24 siswa atau $77,42 \%$. Dari hasil pengamatan dan tes awal yang dilakukan penulis terhadap siswa kelas VI, dapat diperoleh keterangan bahwa pelaksanaan pembelajaran IPA mengalami permasalahan yang harus diperbaiki. Hal ini dibuktikan dengan keadaan siswa yang belum mampu mengerjakan soal yang diberikan, dikarenakan soal yang diberikan belum pernah dipelajari, dan cara mengajar guru yang masih menggunakaan metode ceramah sehingga siswa belum semuanya mengerti tentang pelajaran yang dipelajari setiap harinya.

Pada pertemuan siklus I pertemuan 1 hasil perolehan evaluasi siswa memperoleh nilai rata-rata sebesar 49,58 dengan ketuntasan 
belajar 38,7 \%. Untuk lebih jelasnya dapat dilihat pada Tabel 2 di bawah ini:

Tabel 2. Persentase Ketuntasan Hasil Belajar Siswa Siklus I

\begin{tabular}{|c|c|c|c|}
\hline \multicolumn{4}{|c|}{ Pertemuan 1} \\
\hline No. & Ketuntasan & $\begin{array}{c}\text { Jumlah } \\
\text { Siswa }\end{array}$ & Presentase \\
\hline 1. & Tuntas & 12 & $38,7 \%$ \\
\hline 2. & $\begin{array}{l}\text { Belum } \\
\text { Tuntas }\end{array}$ & 19 & $61,3 \%$ \\
\hline & Jumlah & 31 & $100 \%$ \\
\hline
\end{tabular}

Berdasarkan tabel di atas dapat diketahui, dari 31 siswa terdapat 12 siswa atau $38,7 \%$ yang sudah mencapai ketuntasan belajar atau telah mencapai KKM sebesar 71, sedangkan siswa yang memperoleh nilai di bawah KKM ada 19 siswa atau 61,3\%. Hal-hal yang menyebabkan pada siklus I pertemuan 1 sudah mencapai nilai KKM sebesar 71 dikarenakan penulis sudah menggunakan model pembelajaran STAD karena model pembelajaran ini sangat mengutamakan ketelitian, dan kerjasama antar siswa, siswa dapat belajar dengan penuh makna sehingga pada saat pembelajarannya siswa dapat mengerjakan soal dengan mudah.

Perolehan nilai rata-rata hasil belajar pada pembelajaran siklus I pertemuan 2 ini memperoleh nilai ratarata sebesar 57,08 dengan ketuntasan belajar sebesar $61,29 \%$. Perolehan nilai siswa dapat dilihat pada Tabel 3 di bawah ini:

Tabel 3. Persentase Hasil Belajar Siswa pada Siklus I Pertemuan 2

\begin{tabular}{|c|c|c|c|}
\hline No. & Ketuntasan & $\begin{array}{c}\text { Jumlah } \\
\text { Siswa }\end{array}$ & Persentase \\
\hline 1. & Tuntas & 19 & $61,29 \%$ \\
\hline 2. & $\begin{array}{c}\text { Belum } \\
\text { Tuntas }\end{array}$ & 22 & $38,71 \%$ \\
\hline \multicolumn{2}{|c|}{ Jumlah } & 31 & $100 \%$ \\
\hline
\end{tabular}

Berdasarkan tabel di atas, dapat diketahui peroleh nilai hasil belajar IPA yang diperoleh siswa pada siklus I pertemuan 2 masih ada 22 siswa atau $38,71 \%$ yang mengalami kesulitan dalam belajar karena hasil belajar yang diperolehnya masih di bawah KKM 71. Sedangkan siswa yang sudah mencapai ketuntasan belajar ada 19 siswa atau $61,29 \%$ hal ini dikarenakan soal yang diberikan, siswa sudah lebih mengerti dan memahami tentang pelajaran yang telah dipelajari sebelumnya, soal yang diberikan kepada siswa sudah diperbaiki kembali. Adapun penyebab hasil belajar siswa yang belum mencapai nilai KKM pada siklus I pertemuan 2 yaitu: siswa belum mampu menjawab soal yang diberikan oleh guru dan siswa kurang konsentrasi untuk menjawab soal tersebut.

Perolehan nilai rata-rata hasil belajar pada pembelajaran siklus II ini memperoleh niali rata-rata sebesar 71,6 
dengan ketuntasan belajar sebesar 83\%. Perolehan nilai siswa dapat dilihat pada Tabel 4 di bawah ini:

Tabel 4. Persentase Hasil Belajar Siswa pada Siklus 2

\begin{tabular}{|c|c|c|c|}
\hline No. & Ketuntasan & $\begin{array}{c}\text { Jumlah } \\
\text { Siswa }\end{array}$ & Persentase \\
\hline 1. & Tuntas & 26 & $83,87 \%$ \\
\hline 2. & $\begin{array}{c}\text { Belum } \\
\text { Tuntas }\end{array}$ & 5 & $16,13 \%$ \\
\hline \multicolumn{2}{|c|}{ Jumlah } & 31 & $100 \%$ \\
\hline
\end{tabular}

Berdasarkan tabel di atas, dapat diketahui peroleh nilai hasil belajar Matematiak yang diperoleh siswa pada siklus II masih ada 5 siswa atau $16,13 \%$ yang masih mengalami kesulitan karena hasil belajar yang diperolehnya masih di bawah KKM 71. Sedangkan siswa yang sudah mencapai ketuntasan belajar ada 26 siswa atau $83,87 \%$ hal ini dikarenakan siswa sudah lebih mengerti dan memahami tentang pelajaran yang telah dipelajari sebelumnya, soal yang diberikan kepada siswa telah diperbaiki kembali.

\subsection{Pembahasan}

Penelitian dengan menerapkan model pembelajaran STAD, pada tes awal memperoleh nilai rata-rata sebesar 50,41 dengan persentase ketuntasan $29,17 \%$, sedangkan untuk pertemuan siklus I pertemuan 1, siklus I pertemuan 2 dan siklus II, telah mengalami peningkatan hasil belajar yang signifikan. Untuk perolehan nilai rata-rata dan persentase ketuntasan hasil belajar pada siklus I pertemuan 1 sebesar 49,58(38,7\%), sedangkan pada siklus I pertemuan 2 sebesar 57,08 $(61,29 \%)$ ketuntasan belajar yang dicapai pada siklus I pertemuan 1 dan 2 sudah melebihi $50 \%$ hal ini dikarenakan siswa sudah bisa menjawab soal yang diberikan oleh guru, dan cara pembelajaran dengan menggunakan model pembelajaran STAD dapat meningkatkan hasil belajar siswa. Sedangkan pada siklus II perolehan nilai rata-rata 71,6 dan ketuntasan sebesar $83 \%$. Peningkatan yang terjadi pada siklus I pertemuan 2 dan siklus II sebesar $21 \%$ karena telah adanya perbaikan yang dilakukan oleh guru pada setiap siklusnya. Perbandingan hasil belajar siswa pada setiap siklusnya dapat dilihat pada Gambar 1 berikut ini: 


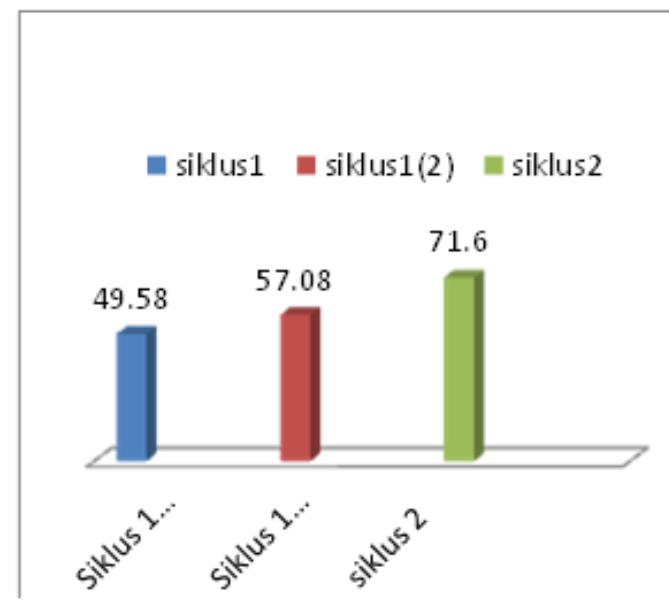

Gambar 1. Perbandingan Nilai Ratarata Hasil Belajar Siswa

Dari uraian di atas, dapat dilihat bahwa perolehan hasil belajar siswa pada setiap siklusnya telah menunjukan adanya perubahan. pengertian hasil belajar adalah prestasi belajar yang telah dicapai dan diwujudkan baik dalam angka maupun kata-kata dalam dunia pendidikan. Selain perolehan hasil belajar siswa yang meningkat, perolehan pelaksanaan pembelajaran dan aktivitas siswa seperti pada saat bekerjasama dalam kelompok, menjawab pertanyaan yang diberikan guru pun telah mengalami peningkatan pada setiap siklusnya. Untuk perolehan nilai pelaksanaan pada siklus I pertemuan 1 memperoleh nilai sebesar 49,58, siklus I pertemuan 2 memperoleh nilai 57,08 dan siklus II mencapai nilai sebesar 71,6 mengalami peningkatan sebesar 18,27 , sedangkan untuk perolehan nilai aktivitas siswa pada siklus I pertemuan 1 memperoleh nilai sebesar 60,8, siklus I pertemuan 2 memperoleh nilai sebesar 68,3 dan pada siklus II mencapai nilai 72,5 mengalami peningkatan sebesar 7,95.

\section{SIMPULAN}

Berdasarkan permasalahan penelitian serta temuan dan pembahasan, diperoleh kesimpulan bahwa pembelajaran dengan menerapkan model pembelajaran STAD dapat meningkatkan hasil belajar IPA dengan materi konduktor dan isolator pada siswa kelas VI di Sekolah Dasar Negeri Balandongan Kecamatan Caringin Kabupaten Bogor. Pada setiap siklusnya terlihat bahwa telah terjadi peningkatan dalam hasil belajar, kinerja guru, dan aktivitas siswa sehingga secara umum pembelajaran dengan menerapkan model pembelajaran STAD mendapat respon positif, baik dari siswa maupun dari guru. 


\section{DAFTAR PUSTAKA}

Arikunto, Suharsini.

2007.

Penelitian

Tindakan

Kelas,Jakarta : Bumi aksara.

Djamarah, Sytaiful.B dan Zain,Azwan,2006 Startegi

Belajar Mengajar, Rineka Cipta.

Dyah, Suryani Skripsi 2011 Skripsi Yogyakarta,FE UNY.

Erna Suwangsih dan Tiurlani. 2006 Model pembelajaran Matematika. Bandung : penerbit UPI Press.

Isjoni dan Arif ismail 2008 .Model model pembelajaran mutakhir Yogyakarta Pustaka pelajar

Nina Mulyani.2005. Penelitian Tindakan kelas. Parungpanjang. Bogor.

Sep Iton. 2003. Skripsi. Sukabumi STKIP.PGRI.

Sri, Rahayu Pudjiastuti 2006. Metode Penelitian Tindakan Kelas/
Jakarta; STKIP Press, 2006. h. 106).

Sujana, Nana 2004, Penilaian hasil proses belajar mengajar Bandung: Rosda.

Susilo, 2007 Panduan Penelitian Tindakan Kelas, Jogyakarta Pustaka Book Publisher,

Suroso, Wihihadmoko. Model-model Pembelajaran Efektif. http://id.wordpress.com.

(http://bisnis3x.blogspot.com/2009/10 /pengertian sikap tingkah laku)

(http:/technoly13.wordpresst.com/200 9/11/17/menumbuhkan motivasi pada siswa)

(http://idshvoong.com/social.sciences/e ducation/2264172) 